

2014, vol. 72, 139-150

http://dx.doi.org/10.12657/denbio.072.012

\author{
Andrzej M. Jagodziński, Izabela Katucka, Pawet Horodecki, \\ Jacek Oleksyn
}

\section{Aboveground biomass allocation and accumulation in a chronosequence of young Pinus sylvestris stands growing on a lignite mine spoil heap}

Received: 19 April 2013; Accepted: 05 June 2014

\begin{abstract}
It is not clear to what extent trees growing on anthropogenic sites change their growth and biomass allocation to different organs. We assessed the aboveground biomass in a chronosequence of six Scots pine monocultures (between 6 and 20 years old) to examine how precisely the site-specific or control allometric equations may reflect the value of biomass accumulation and allocation in stands growing in harsh site conditions on the overlayer spoil heap made as a result of opencast brown coal mining. The site is characterized by poor edaphic and water conditions and nutrient deficiency. The control equations were developed from Scots pine stands growing on post-agricultural lands in the close vicinity of the spoil heap. We found that equation type significantly influenced results of predicted biomass accumulation for all biomass components studied (although results were only marginally significant for total aboveground biomass, $P=0.08)$. Total aboveground biomass in younger stands (6-9 years old) estimated using site-specific equations was $>40 \%$ higher and for older stands (17-20 years old) from 7 to $27 \%$ lower than estimated using equations developed for the control sites. Our study revealed that under harsh environmental conditions in spoil heaps, biomass of young Scots pine stands significantly differ from values calculated based on control equations developed for more fertile soils with better water conditions in the same region. The control biomass equations may not be suitable to estimate biomass accumulation in stands growing on infertile habitats with poor water conditions, if the control equations are developed for nearby stands but growing under better site conditions.
\end{abstract}

Additional key words: allometric equations, Scots pine, biomass allocation, site conditions, opencast mining, age chronosequence

Addresses: Andrzej M. Jagodziński, Polish Academy of Sciences, Institute of Dendrology, Parkowa 5, PL-62-035 Kórnik, Poland; Poznań University of Life Sciences, Faculty of Forestry, Department of Forest Protection, Wojska Polskiego 71c, PL-60-625 Poznań, Poland, e-mail: amj@man.poznan.pl Izabela Kałucka, University of Łódź, Faculty of Biology and Environmental Protection, Banacha 12/16, PL-90-237 Łódź, Poland Paweł Horodecki, Jacek Oleksyn, Polish Academy of Sciences, Institute of Dendrology, Parkowa 5, PL-62035 Kórnik, Poland 


\section{Introduction}

Increasing human activities affect most of the terrestrial surface of the globe, creating many anthropogenic sites requiring reclamation. Open-pit mining is one of the anthropogenic activities resulting in large-scale land transformation due to extreme soil disturbance. The spoil heaps made of the subsoil and overburden from brown coal mining are characterized by low soil organic matter content, extremely low fertility, and poor physicochemical and biological properties, limiting their quality and functions (Ussiri and Lal 2005). The restoration of lands affected by surface coal mining is an increasingly important concern in many countries (e.g. Filcheva et al. 2000; Bell 2001; Shrestha and Lal 2006; Pietrzykowski and Krzaklewski 2007). Large portions of these areas are reclaimed for forestry (Smith 2002).

Since forests are the largest terrestrial carbon storages, the estimation of tree biomass production and partitioning to different organs is an essential step in carbon balance studies (Hamburg 2000; Pregitzer and Euskirchen 2004; Harris et al. 2006; Litton et al. 2007; Lorenz and Lal 2010; Reich 2011). Such estimates of biomass are also important for monitoring of annual and long term changes in forest productivity and modeling of macro- and micro-nutrient cycling (Oleksyn et al. 2003; Reich and Oleksyn 2004). Although there is a vast body of data on biomass development of forest stands over time, most of them relate to stem biomass and volume (i.e. merchantable timber) as the most valuable parts of forest production (e.g. Ter-Mikaelian and Korzukhin 1997; Zianis et al. 2005; Muukkonen and Mäkipää 2006), while other aboveground biomass components are often omitted. Therefore, assessing the potential for longterm carbon sequestration in aboveground forest biomass requires consideration of needle and branch biomass, which are more dynamic and flexible than the stem component of biomass (e.g. Jagodziński and Kałucka 2008; Jelonek et al. 2011; Pietrzykowski and Socha 2011). Moreover, most allometric equations used for estimation of tree biomass were developed for natural or commercial forest sites only moderately affected by human activity (e.g. traditional forest management practice), and it is not clear whether they may be used for a growing number of degraded areas (Hamburg 2000).

Chronosequence studies are widely used for assessing long-term changes in forest dynamics and quantifying standing biomass (e.g. Mund et al. 2002; Law et al. 2003; Kolari et al. 2004; Jagodziński and Kałucka 2010, 2011; Uri et al. 2012; Bijak et al. 2013). The assumptions of that method are that the even-aged monospecific forest stands of an age sequence represent consecutive stages of forest stand development over time and that the selected stands have developed under comparable and fairly homogenous growth conditions (soil, climate, initial stand density, management history, etc.). Although biomass allocation patterns in Scots pine stands have been intensely studied, the overwhelming majority of studies concern single stands, limiting the ability to estimate biomass changes over time for stands growing under similar site conditions (Gower et al. 1994). Thus, the trajectory of changes in aboveground biomass partitioning over time is still insufficiently known for Scots pine, the tree species most often used for land reclamation in Central European countries (Řehounková and Prach 2008). In addition, since most empirical biomass equations for Scots pine are restricted to pole-stage and mature stands (e.g. Zianis et al. 2005; Muukkonen and Mäkipää 2006), some emphasis should be placed on the small diameter tree classes in younger age stages. For example, the estimation of stand-level biomass allocation changes with age in Scots pine have been presented by Ovington (1957) for 12 pine stands (age range: 3-55 years) in Great Britain and Albrektson (1980) in Central Sweden (7-100 years) and for single trees of different ages (18-212 years) grown on two types of forest sites (Myrtillus- and Calluna-type) by Vanninen et al. (1996). In general, published data indicate that stand age, climate conditions, nutrient availability and genetic control are the most important factors influencing aboveground biomass accumulation and allocation (Gower et al. 1994; Vose et al. 1994; Oleksyn et al. 1999; Jagodziński and Kałucka 2008; Poorter et al. 2012; Chmura et al. 2013).

Because pine forests occur across a wide range of environmental and edaphic conditions (cf. Oleksyn et al. 2002), it is possible to examine how these factors influence biomass accumulation and allocation patterns (Knight et al. 1994). It is known that changes in stand development due to differences in site conditions may alter biomass allocation trajectories and tree allometry (e.g. Vanninen and Mäkelä 2005; Poorter et al. 2012). On the other hand, Vanninen et al. (1996) found that trees growing under two different growth conditions followed the same pattern of development for relative shares of biomass partitioning, but growth was faster on the more fertile site.

It is not clear whether allometric equations developed for forest habitats managed usually in sustained way may be applied to calculate biomass allocation and accumulation for stands growing under highly transformed and difficult conditions of low nutrient and/or water availability, such as mine spoil heaps. Thus, the specific aims of our study were:

(1) to develop suitable allometric equations for individual aboveground biomass components in young Scots pine stands (up to 20 years old) growing under extremely unfavorable site conditions of spoil heaps, 
(2) to estimate aboveground biomass components using site-specific allometric equations and to compare them with biomass estimated using allometric equations developed from the control sites (control equations),

(3) to analyze changes of relative biomass allocation with stand age.

The results obtained from this study may also be useful in further ecological studies, forest management practice and for predicting biomass (and carbon storage) of forest ecosystems affected by human activity, especially by brown coal mining.

\section{Materials and methods}

\section{Study site}

The study was conducted in six Scots pine ( $P i$ nus sylvestris L.) stands aged 6, 9, 11, 15, 17, and 20 years in Bełchatów Forest District, Poland $\left(51^{\circ} 12^{\prime} \mathrm{N}\right.$, $19^{\circ} 25^{\prime}$ E, $400 \mathrm{~m}$ a.s.1.). The study plots were located on Mount Kamieńsk, which is the largest (relative height ca. $180 \mathrm{~m}$, ca. $400 \mathrm{~m}$ a.s.l., base surface 1500 ha) artificial overlayer spoil heap in Poland made as a result of Bełchatów brown coal mining activity (Hołubowicz 1985; Krzaklewski 2005). Detailed description of the research sites is presented by Jagodziński and Kałucka $(2008,2010)$.

Forest reclamation of the area started in the mid1980s, thus the oldest stands are now ca. 30 years old. The most common tree species used for reforestation were Betula pendula (ca. 25\% of the total area), Pinus sylvestris (20\%), Alnus spp. (15\%), Robinia pseudoacacia (12\%), and Quercus spp., Populus spp., Salix spp., Acer spp., Fraxinus spp., and Larix decidua (Forest Management Plan 1997, manuscript). The initial stand density of the Scots pine stands included in this study was ca. 12000 trees per hectare (initial spacing $-1.5 \mathrm{~m} \times 0.6 \mathrm{~m})$. Since the natural mortality of trees was high during the first stage of stand development, only light pre-commercial thinning treatment was applied (except for the 6-year-old stand).

The mine spoil is formed of approximately 1300 million $\mathrm{m}^{3}$ of various Quaternary and Tertiary overburden sediments covering the coal seam, which were mixed, loosened and aerated. The oxidation of pyrite $\left(\mathrm{FeS}_{2}\right)$, the mineral typical for Tertiary substrates, results in severe acidification $(\mathrm{pH}<2.5)$. In cases where such materials had not been isolated inside the mine spoil, but were instead deposited near the spoil surface, extensive amounts of lime (chalk of lake origin from the open pit) and alkaline ash from the nearby lignite-fired power plant were applied to neutralize the high acidity. The spoil substrates are mainly of slightly alkaline sandy-clayey character, low in organic matter (sometimes with brown coal admixture) and are very poor in nutrients. Before establishment of tree stands, the top surface of the heap was sown with mixed grass species and legumes and mineral fertilizer ( $\mathrm{N}$ and $\mathrm{K}-60 \mathrm{~kg} \mathrm{ha}^{-1}, \mathrm{P}-70$ $\mathrm{kg} \mathrm{ha}^{-1}$ ) was applied to enhance the soil substrate (Pietrzykowski et al. 2009). Top soil and humus separated during the mining process as well as lignite and charcoal have been also used for the spoil surface reclamation (Hołubowicz 1985; Kowalik et al. 1999; Krzaklewski 2005; Pająk and Krzaklewski 2007).

Soil analyses were performed in the pine plantations both on the mine spoil and in adjacent postarable land; the structure and physical features were described and $\mathrm{pH}$ and organic $\mathrm{C}, \mathrm{P}, \mathrm{N}$ and $\mathrm{CaCO}_{3}$ content were measured (Świtoniak et al. 2011, 2013). Soil horizons have not yet formed under any of the stands examined on the spoil. The $\mathrm{pH}$ (in $\mathrm{H}_{2} \mathrm{O}$ ) of the dump surface layers was rarely less than 8 (with $\mathrm{CaCO}_{3}$ almost always present), while in the afforested arable land the average $\mathrm{pH}$ was around 5.3 (with $\mathrm{CaCO}_{3}$ always absent). The concentration of $\mathrm{N}$ was about half and that of $\mathrm{P}$ was slightly higher in the mine spoil surface layers as compared to the afforested arable land.

According to long-term meteorological observations (1971-2000) from the closest meteorological station, mean annual temperature is $8.0^{\circ} \mathrm{C}$, mean annual precipitation is $571 \mathrm{~mm}$, and mean growing season length (calculated as the number of days with mean temperature $\geq 5^{\circ} \mathrm{C}$ ) is 213 days (Dubaniewicz 1979; Concise Statistical Yearbook of Poland 2007).

\section{Biomass estimation on mine spoil heap}

In September 2006 we measured diameters at breast height $\left(\mathrm{D}_{1.3 \mathrm{~m}}\right)$ and heights of all trees in two plots in each stand (Table 1) examined on the mine spoil heap. The plot area varied from $300 \mathrm{~m}^{2}$ for the youngest stand to $450-550 \mathrm{~m}^{2}$ for the remaining stands. Since a few trees in the youngest stand had not yet reached the height of $1.3 \mathrm{~m}$, we measured their diameter at a height of $0.5 \mathrm{~m}$ and biomass for these trees was estimated on the basis of diameters at $0.5 \mathrm{~m}$ of height, while for the higher trees on the basis of diameters at $1.3 \mathrm{~m}$ of height.

Seven to nine trees were chosen for destructive harvest in each stand. These were chosen to represent the diameter classes present in each stand (based on the stem diameter frequency distribution for each stand) as well as a range of canopy heights and canopy positions. In total, 46 model trees from six plantations, each representing typically managed, single-species, even-aged Scots pine stands, were chosen for the study. The model trees were harvested in September 2006, and the cones (if present), needles and branches were separated from the main stem. All organs were weighed immediately in the field to obtain their fresh mass. Cones, needles and 
Table 1. Mean $( \pm \mathrm{SE}$ ) characteristics of Scots pine stands growing on spoil heap from brown coal mining and in control sites in Bełchatów (central Poland). One-way ANOVAs were performed separately for the stand density, tree diameters at $1.3 \mathrm{~m}$ height, height of trees and stand basal area. Same letters indicate a lack of statistically significant differences between analyzed stand traits according to Tukey's a posteriori test $(P<0.05)$.

\begin{tabular}{|c|c|c|c|c|c|c|c|c|c|c|c|c|c|c|c|c|}
\hline $\begin{array}{c}\text { Stand age } \\
\text { [years] }\end{array}$ & \multicolumn{2}{|c|}{$\begin{array}{l}\text { Stand density } \\
{\left[\text { trees } \mathrm{ha}^{-1}\right]}\end{array}$} & \multicolumn{2}{|c|}{$\begin{array}{l}\mathrm{D}_{1.3 \mathrm{~m}} \\
{[\mathrm{~cm}]}\end{array}$} & \multicolumn{2}{|l|}{$\begin{array}{c}\mathrm{H} \\
{[\mathrm{m}]}\end{array}$} & \multirow[t]{2}{*}{$\begin{array}{c}\mathrm{G}_{1.3 \mathrm{~m}} \\
{\left[\mathrm{~m}^{2} \mathrm{ha}^{-1}\right]}\end{array}$} & $\begin{array}{c}\text { Stand age } \\
\text { [years] }\end{array}$ & \multicolumn{2}{|c|}{$\begin{array}{l}\text { Stand density } \\
{\left[\text { trees ha } \mathrm{ha}^{-1}\right]}\end{array}$} & \multicolumn{2}{|c|}{$\begin{array}{l}\mathrm{D}_{1.3 \mathrm{~m}} \\
{[\mathrm{~cm}]}\end{array}$} & $\begin{array}{c}\mathrm{H} \\
{[\mathrm{m}]}\end{array}$ & & \multicolumn{2}{|c|}{$\begin{array}{c}\mathrm{G}_{1.3 \mathrm{~m}} \\
{\left[\mathrm{~m}^{2} \mathrm{ha}^{-1}\right]}\end{array}$} \\
\hline \multicolumn{7}{|c|}{ Stands grown on mine spoil heap } & & \multicolumn{9}{|c|}{ Control stands } \\
\hline 6 & $\begin{array}{l}6127 \\
(58)\end{array}$ & $\mathrm{a}$ & $\begin{array}{c}1.44 \\
(0.04)\end{array}$ & e & $\begin{array}{c}1.41 \\
(0.02)\end{array}$ & e & $\begin{array}{cc}0.66 & \mathrm{~d} \\
(0.15) & \end{array}$ & 6 & $\begin{array}{l}9430 \\
(690)\end{array}$ & $\mathrm{a}$ & $\begin{array}{c}1.44 \\
(0.12)\end{array}$ & c & $\begin{array}{c}1.83 \\
(0.01)\end{array}$ & d & $\begin{array}{l}1.79 \\
(0.44)\end{array}$ & c \\
\hline 9 & $\begin{array}{l}5744 \\
(119)\end{array}$ & $\mathrm{ab}$ & $\begin{array}{l}2.78 \\
(0.07)\end{array}$ & $\mathrm{d}$ & $\begin{array}{l}2.44 \\
(0.04)\end{array}$ & $d$ & $\begin{array}{c}4.03 \\
(0.60)\end{array}$ & 10 & $\begin{array}{l}3890 \\
(150)\end{array}$ & bc & $\begin{array}{c}6.48 \\
(0.07)\end{array}$ & $\mathrm{b}$ & $\begin{array}{c}4.35 \\
(0.02)\end{array}$ & c & $\begin{array}{l}13.92 \\
(0.21)\end{array}$ & b \\
\hline 11 & $\begin{array}{l}5220 \\
(120)\end{array}$ & $\mathrm{bc}$ & $\begin{array}{l}2.82 \\
(0.06)\end{array}$ & d & $\begin{array}{c}2.57 \\
(0.03)\end{array}$ & $\mathrm{d}$ & $\begin{array}{c}3.67 \\
(0.15)\end{array} \quad \mathrm{d}$ & 16 & $\begin{array}{l}5155 \\
(225)\end{array}$ & $\mathrm{b}$ & $\begin{array}{c}7.01 \\
(0.40)\end{array}$ & $\mathrm{b}$ & $\begin{array}{c}7.09 \\
(0.21)\end{array}$ & $\mathrm{b}$ & $\begin{array}{l}22.07 \\
(1.23)\end{array}$ & $a b$ \\
\hline 15 & $\begin{array}{l}5237 \\
(97)\end{array}$ & $\mathrm{bc}$ & $\begin{array}{l}5.76 \\
(0.08)\end{array}$ & c & $\begin{array}{c}4.94 \\
(0.09)\end{array}$ & c & $\begin{array}{l}14.83 \\
(1.14)\end{array}$ & 28 & $\begin{array}{l}1914 \\
(452)\end{array}$ & c & $\begin{array}{l}13.34 \\
(0.78)\end{array}$ & a & $\begin{array}{l}13.77 \\
(0.18)\end{array}$ & a & $\begin{array}{l}27.47 \\
(3.20)\end{array}$ & $\mathrm{a}$ \\
\hline 17 & $\begin{array}{l}4910 \\
(90)\end{array}$ & c & $\begin{array}{c}6.71 \\
(0.09)\end{array}$ & $\mathrm{b}$ & $\begin{array}{c}5.59 \\
(0.10)\end{array}$ & $\mathrm{b}$ & $\begin{array}{l}18.91 \\
(0.59)\end{array} \quad \mathrm{b}$ & & & & & & & & & \\
\hline 20 & $\begin{array}{l}4982 \\
(109) \\
\end{array}$ & c & $\begin{array}{c}8.29 \\
(0.11) \\
\end{array}$ & $\mathrm{a}$ & $\begin{array}{c}8.01 \\
(0.17) \\
\end{array}$ & $\mathrm{a}$ & $\begin{array}{l}29.36 \\
(0.48)\end{array}$ & & & & & & & & & \\
\hline $\begin{array}{c}\text { ANOVA } \\
\mathrm{P}>\mathrm{F}\end{array}$ & 0.00 & & $<0.0$ & & $<0.0$ & & $<0.0001$ & & 0 . & & 000 & & $<$ & & 0. & \\
\hline
\end{tabular}

Abbreviations: $\mathrm{D}_{1.3 \mathrm{~m}}$ - diameter at $1.3 \mathrm{~m}$ height of trees; $\mathrm{H}$ - height of trees; $\mathrm{G}_{1.3 \mathrm{~m}}-$ stand basal area

branches were weighed separately for each whorl. Fresh mass of stem wood with bark and branches was weighed with at least $50 \mathrm{~g}$ accuracy, and fresh mass of needles and cones with $1 \mathrm{~g}$ accuracy. To calculate stem wood and bark biomass separately, $10 \mathrm{~cm}$ thick cross-sections of stems were cut from the middle of every $1 \mathrm{~m}$ segment of the stem (e.g. $0.5,1.5,2.5 \mathrm{~m}$, etc.). All stem cross-sections were weighed to obtain their fresh mass. Bark was separated from wood in the laboratory and both were dried to constant mass at $65{ }^{\circ} \mathrm{C}$ to obtain dry mass of each cross-section (bark and wood). Dry mass of wood and bark for the entire tree was calculated using the fresh masses of the $1 \mathrm{~m}$ stem segments. To obtain the dry mass of branches, needles and cones, samples of each were taken, weighed to obtain fresh mass and then oven dried to a constant mass $\left(65^{\circ} \mathrm{C}\right)$ in a drier with forced air circulation (ULE 600; Memmert GmbH+Co.KG, Germany).

To calculate biomass of various components of trees we developed allometric equations of the form $\mathrm{Y}=\mathrm{aD}{ }^{\mathrm{b}}$, where $\mathrm{Y}$ is dry biomass of the particular tree component $(\mathrm{kg}), \mathrm{D}$ is diameter at breast height (or at $0.5 \mathrm{~m}$ for trees lower than $1.3 \mathrm{~m}$ in height) in $\mathrm{cm}$, and $\mathrm{a}$ and $\mathrm{b}$ are constant equation coefficients. We tested different models, and selected the one with the best fit by judging the resulting MSE (mean squared error) and the adjusted coefficient of multiple determination $\left(\mathrm{R}^{2}\right)$. Allometric equations were developed for the following biomass components: total aboveground biomass $(\mathrm{AB})$, total aboveground woody biomass (ABW), branch biomass (BR), foliage biomass (FL), stem bark biomass (SB), stem wood biomass (SW) and total stem biomass (ST; $\mathrm{SW}+\mathrm{SB})$. Since most of the trees produced only a small number of cones, they were not modeled, but were included in final estimates of total aboveground woody biomass. The biomass functions were applied to all standing trees to provide an estimate of the plot biomass, which was then upscaled to estimate the biomass per hectare.

\section{Biomass estimation on control stands}

To evaluate the potential influence of site conditions on biomass allocation trajectories, we developed allometric equations for all biomass components based on model trees harvested in four pure Scots pine monocultures growing on post-agricultural lands in the close vicinity of the spoil heap $\left(51^{\circ} 11^{\prime} 03.5^{\prime \prime}\right.$ to $51^{\circ} 18^{\prime} 14.0^{\prime \prime} \mathrm{N}, 19^{\circ} 22^{\prime} 39.1^{\prime \prime}$ to $19^{\circ} 27^{\prime} 09.7^{\prime \prime} \mathrm{E}, \mathrm{ca} .195$ $210 \mathrm{~m}$ a.s.l.). The initial stand density of the stands ranged from 11000 to 12000 trees per hectare (initial spacing $-1.5 \mathrm{~m} \times 0.6 \mathrm{~m})$. Regular light pre-commercial thinning treatments were applied when stands became overcrowded (except for the 6-year-old stand). Detailed description of the research sites is presented by Jagodziński and Kałucka (2011).

We used 31 model trees in total ( 7 to 8 trees from each stand), harvested from stands $6,10,16$, and 28 years old, and representing the range of diameters and heights of trees present in each stand. The range of diameters at breast height of model trees amounted from 0.4 to $20.6 \mathrm{~cm}$ and heights from 1.33 to 15.72 $\mathrm{m}$. The allometric equations were developed with the same method as for stands grown on lignite mine spoil heap. The allometric equations developed were then used to estimate the biomass of each stand grown on the spoil heap. Because some of the trees from the youngest stand (6 years old) on the spoil heap did not reach a height of $1.3 \mathrm{~m}$, we also developed additional set of control allometric equations based on 
Table 2. Site-specific allometric equations for different biomass components in Scots pine stands growing on spoil heap from brown coal mining in Bełchatów.

\begin{tabular}{|c|c|c|c|c|c|c|}
\hline \multirow{2}{*}{$\begin{array}{c}\text { Biomass } \\
\text { component } \\
\text { [kg d.m. }]\end{array}$} & \multicolumn{2}{|c|}{ Range of } & \multicolumn{2}{|c|}{ Parameters } & \multirow[b]{2}{*}{$r^{2}$} & \multirow[b]{2}{*}{$\mathrm{p}$} \\
\hline & $\begin{array}{c}\mathrm{D} \\
{[\mathrm{cm}]}\end{array}$ & $\begin{array}{c}\mathrm{H} \\
{[\mathrm{m}]}\end{array}$ & $\mathrm{a}$ & $\mathrm{b}$ & & \\
\hline $\mathrm{AB}$ & & & 0.0748323777348045 & 2.38437505891202 & 0.98 & $<0.0001$ \\
\hline ABW & & & 0.0422086921498093 & 2.55105286119757 & 0.99 & $<0.0001$ \\
\hline ST & & & 0.0322515302020289 & 2.48789163610786 & 0.99 & $<0.0001$ \\
\hline SW & $0.3-16.6$ & $1.38-10.90$ & 0.0197990857417363 & 2.62224591357882 & 0.99 & $<0.0001$ \\
\hline SB & & & 0.0268075934864441 & 1.76559638769715 & 0.99 & $<0.0001$ \\
\hline BR & & & 0.0131997594681446 & 2.57328455139068 & 0.95 & $<0.0001$ \\
\hline FL & & & 0.0927894516943060 & 1.50560694997731 & 0.97 & $<0.0001$ \\
\hline
\end{tabular}

For the stands we developed allometric equations of the form: Biomass component $[\mathrm{kg} \mathrm{d} . \mathrm{m}]=.\mathrm{aD}^{\mathrm{b}}$, where $\mathrm{D}$ - diameter at breast height [cm], $\mathrm{H}$ - height $[\mathrm{m}]$, a and $\mathrm{b}$ - equation coefficients. Abbreviations for tree biomass components: total aboveground biomass (AB), total aboveground woody biomass (ABW), branch biomass (BR), foliage biomass (FL), stem bark biomass (SB), stem wood biomass (SW) and total stem biomass (ST; SW+SB).

diameters at $0.5 \mathrm{~m}$ in height of trees harvested from post-agricultural lands (equations not shown).

We calculated biomass of different organs of trees per hectare using two types of allometric equations:

(1) site-specific for mine spoil heap conditions,

(2) control equations developed from the post-agricultural lands in the close vicinity of the spoil heap (control stands).

\section{Statistical analyses}

All statistical analyses were conducted using JMP 10.0.0. (SAS Institute Inc., Cary, NC, USA; http:// www.sas.com/). ANOVAs were performed to show the differences among stand traits analyzed and if significant differences were noted, multiple comparisons were carried out based on Tukey's test for equal sample sizes.

\section{Results}

\section{Allometric equations}

On the basis of harvested trees $(n=46)$, site-specific allometric equations were developed to predict different aboveground biomass components in Scots pine stands grown on the mine spoil heap (Table 2). The $\mathrm{R}^{2}$ values of the relationships among diameter $(\mathrm{D}, \mathrm{cm})$ and biomass of trees were highly significant $(P<0.0001)$ and ranged between 0.95 and 0.99 . In general, the strongest relationships were found for most of woody components of tree biomass, i.e. total stem $\left(\mathrm{R}^{2}=0.99\right)$, stem wood $\left(\mathrm{R}^{2}=0.99\right)$, stem bark $\left(\mathrm{R}^{2}=0.99\right)$, and total aboveground woody biomass $\left(\mathrm{R}^{2}=0.99\right)$. Slightly weaker relationships were found for foliage biomass $\left(\mathrm{R}^{2}=0.97\right)$ and branch biomass $\left(\mathrm{R}^{2}=0.95\right)$. We checked for potential differences between the biomass estimates of Scots pine growing on spoil heaps using equations including trees of all age classes and age-class specific equations. We found that the estimates using these equations were not significantly different, with the uncertainty level not exceeding the accepted level of 10\% (Hamburg 2000; data not shown).

The control equations for the Scots pine stands growing on post-agricultural lands in the close vicinity of the spoil heap (based on 31 trees harvested) were also highly significant (Table 3 ). The $\mathrm{R}^{2}$ for the allometric equations ranged from 0.93 for stem bark to 0.99 for total aboveground woody biomass and stem biomass. Generally, the strongest relationships were also found for woody components of tree biomass.

Table 3. Allometric equations for different biomass components in control stands of Scots pine growing in close vicinity of the mine spoil heap in Bełchatów.

\begin{tabular}{|c|c|c|c|c|c|c|}
\hline \multirow{2}{*}{$\begin{array}{l}\text { Biomass } \\
\text { component } \\
\text { [kg d.m.] }\end{array}$} & \multicolumn{2}{|c|}{ Range of } & \multicolumn{2}{|c|}{ Parameters } & \multirow[b]{2}{*}{$r^{2}$} & \multirow[b]{2}{*}{$\mathrm{p}$} \\
\hline & $\begin{array}{l}\mathrm{D}_{1.3 \mathrm{~m}} \\
{[\mathrm{~cm}]}\end{array}$ & $\begin{array}{c}\mathrm{H} \\
{[\mathrm{m}]}\end{array}$ & $\mathrm{a}$ & $\mathrm{b}$ & & \\
\hline $\mathrm{AB}$ & & & 0.0518815506516566 & 2.55911917376072 & 0.98 & $<0.0001$ \\
\hline ABW & & & 0.0366679503089246 & 2.65342520564160 & 0.99 & $<0.0001$ \\
\hline ST & & & 0.0327897785202399 & 2.60457358821080 & 0.99 & $<0.0001$ \\
\hline SW & $0.4-20.6$ & $1.33-15.72$ & 0.0231587556549311 & 2.68216788047766 & 0.98 & $<0.0001$ \\
\hline SB & & & 0.0158849768158299 & 2.10904899895454 & 0.93 & $<0.0001$ \\
\hline BR & & & 0.0041504627396663 & 2.86677656568688 & 0.94 & $<0.0001$ \\
\hline FL & & & 0.0836025380588780 & 1.46928272571661 & 0.94 & $<0.0001$ \\
\hline
\end{tabular}

For the stands we developed allometric equations of the form: Biomass component [kg d.m.] $=\mathrm{aD}^{\mathrm{b}}$, where $\mathrm{D}-$ diameter at breast height $[\mathrm{cm}], \mathrm{H}-$ height $[\mathrm{m}], \mathrm{a}$ and $\mathrm{b}$ - equation coefficients. Abbreviations as in Table 2. 


\section{Biomass accumulation estimates based on site-specific and control equations}

We found that equation type (site-specific or control referring to the nearby control stands), significantly influenced the value of biomass accumulation calculated on a per area basis for all biomass components measured, although differences for total aboveground biomass were marginally significant (Table 4). In addition, we found a highly significant influence of stand age on biomass accumulation per stand area and an interaction between site-specific vs. control equation and stand age.

Total aboveground biomass per area in younger stands (6- and 9-year-old) estimated on the basis of site-specific allometric equations was higher than estimated on the basis of allometric equations established on model trees from the control stands (Table 5). In those stands the highest statistically significant differences were noted for branch and foliage biomass. At age 11 most of biomass components were higher when estimated by control equations, except foliage biomass, and the differences were statistically significant. In older stands $(15,17$, and 20 years old) the biomass calculated using control allometric equations was generally higher than estimated on the basis of site-specific biomass equations. At age 15 the statistically significant differences were noted only for branch and foliage biomass, whereas at ages 17 and 20 years, most of biomass components differed significantly. We found that for most of the stands the highest differences among estimated biomass components were for foliage and branch biomass. For example, foliage biomass estimated by site-specific equations was $88,138,32,48$ and $19 \%$ higher for stands $6,9,11,15$, and 17 years old, respectively, in comparison with biomass calculated by equations established for the control stands. Similarly, the branch biomass was $188,110,71,28$, and $2 \%$ higher for stands 6,9 ,

Table 4. Results of two-way ANOVA showing the influence of equation type (site-specific or control delivered from nearby control stand), age and equation type $\times$ stand age on different biomass components per stand area basis for Scots pine stands growing on spoil heaps from brown coal mining in Bełchatów. Abbreviations as in Table 2.

\begin{tabular}{cccc}
\hline \multirow{2}{*}{$\begin{array}{c}\text { Biomass } \\
\text { component } \\
{\left[\mathrm{kg} \mathrm{ha}^{-1}\right]}\end{array}$} & $\begin{array}{c}\text { Equation } \\
\text { type }\end{array}$ & $\begin{array}{c}\text { Stand } \\
\text { age }\end{array}$ & $\begin{array}{c}\text { Equation type } \times \\
\text { Stand age }\end{array}$ \\
\cline { 2 - 4 } $\mathrm{AB}$ & 0.0829 & $<0.0001$ & 0.0009 \\
$\mathrm{ABW}$ & 0.0029 & $<0.0001$ & 0.0007 \\
$\mathrm{ST}$ & $<0.0001$ & $<0.0001$ & $<0.0001$ \\
$\mathrm{SW}$ & $<0.0001$ & $<0.0001$ & $<0.0001$ \\
$\mathrm{SB}$ & $<0.0001$ & $<0.0001$ & $<0.0001$ \\
$\mathrm{BR}$ & $<0.0001$ & $<0.0001$ & 0.0021 \\
$\mathrm{FL}$ & $<0.0001$ & $<0.0001$ & 0.0121 \\
\hline
\end{tabular}

15,17 , and 20 years old, respectively, when calculated by site-specific equations.

Comparing remaining woody biomass components (total aboveground woody, stem, stem bark and stem wood biomass) we found that the biomass storage was not statistically different for stands 6 , 9 , and 15 years old, regardless of the model origin. However, distinct differences for the biomass components studied were found for stands 11,17 , and 20 years old - for these stands biomass of all components was significantly higher when calculated by control allometric equations (Table 5).

In addition our data showed that equation origin significantly affected estimated proportional allocations of biomass components within total aboveground biomass $(P<0.0001$ for all biomass components). Moreover, we found a significant influence of stand age on the proportions of all biomass components in aboveground mass and an interaction between sources of equations and the stand age $(P<0.0001)$.

Our study revealed that proportions of biomass components within total aboveground biomass are significantly different when calculated by site-specific and control allometric equations (Table 6). The lack of significant differences was found only for biomass allocation to branches for 11-year-old stand. In general, the proportional allocation of aboveground mass to foliage and branches was underestimated when calculated on the basis of control allometric equations developed for the Scots pine stands growing on post-agricultural lands in the close vicinity of the spoil heap (control sites). For example, proportional allocation to foliage was 41,33 and $36 \%$ of total aboveground biomass for stands 6,9 , and 11 years old, respectively, when calculated by site-specific allometric equations and 34,21 and $25 \%$ when control allometric equations were used. A similar pattern was observed for proportion of branch mass of the stands studied. Finally, the differences in proportional biomass allocation calculated using site-specific and control allometric equations were similar in older stands.

\section{Biomass accumulation vs. stand age}

As expected, our data showed highly significant differences in particular biomass components calculated on area basis for a chronosequence of stands and for both types of allometric equations used in the study (Table 5). The total aboveground biomass increased with stand age and varied from $5.3 \mathrm{Mg}$ $\mathrm{ha}^{-1}$ in the youngest stand to $52.6 \mathrm{Mg} \mathrm{ha}^{-1}$ in the oldest stand, when site-specific allometric equations were used for biomass estimation, and from 3.5 to 66.6 $\mathrm{Mg} \mathrm{ha}{ }^{-1}$, when biomass was calculated on the basis of control equations developed for the control 
Table 5. Mean biomass components $\left[\mathrm{Mg} \mathrm{ha}^{-1} ; \pm \mathrm{SE}\right]$ in Scots pine stands differing in age estimated on the basis of two equation types (site-specific and control delivered from nearby control stands). One-way ANOVAs were performed separately for particular biomass components to check differences among stands differing in age (horizontally) and within the stand among biomass obtained by site-specific and control equations (vertically). Same letters indicate a lack of statistically significant differences between analyzed stand traits according to Tukey's a posteriori test $(P<0.05)$.

\begin{tabular}{|c|c|c|c|c|c|c|c|c|}
\hline \multirow{2}{*}{$\begin{array}{l}\text { Biomass } \\
\text { component } \\
{\left[\mathrm{Mg} \mathrm{ha}^{-1}\right]}\end{array}$} & \multirow{2}{*}{$\begin{array}{l}\text { Equation } \\
\text { type }\end{array}$} & \multicolumn{6}{|c|}{ Stand age } & \multirow{2}{*}{$\begin{array}{c}\text { ANOVA } \\
\mathrm{P}>\mathrm{F}\end{array}$} \\
\hline & & 6 & 9 & 11 & 15 & 17 & 20 & \\
\hline \multirow[t]{2}{*}{$\mathrm{AB}$} & site-specific & $5.3(0.8) c$ & $9.8(1.4) c$ & $11.0(0.2) \mathrm{c}$ & $34.0(2.8) \mathrm{b}$ & $39.8(1.3) b$ & $52.6(1.2) \mathrm{a}$ & $<0.0001$ \\
\hline & control & $\begin{array}{c}3.5(0.5) \mathrm{e} \\
65 \% * 1\end{array}$ & $\begin{array}{c}6.7(1.3) \text { de } \\
69 \%^{*}\end{array}$ & $\begin{array}{c}12.1(0.1) \mathrm{d} \\
110 \%^{* *}\end{array}$ & $\begin{array}{c}30.8(2.7) \mathrm{c} \\
91 \%^{\mathrm{ns}}\end{array}$ & $\begin{array}{c}42.6(1.4) \mathrm{b} \\
107 \%^{\mathrm{ns}}\end{array}$ & $\begin{array}{c}66.6(1.5) \mathrm{a} \\
127 \%^{* *}\end{array}$ & $<0.0001$ \\
\hline \multirow[t]{2}{*}{ ABW } & site-specific & $3.1(0.5) \mathrm{c}$ & $6.5(0.9) c$ & $7.0(0.2) c$ & $27.5(2.3) b$ & $33.0(1.1) \mathrm{b}$ & $47.7(1.1) \mathrm{a}$ & $<0.0001$ \\
\hline & & $\begin{array}{c}2.3(0.3) \mathrm{d} \\
73 \%^{\mathrm{ns}}\end{array}$ & $\begin{array}{c}5.3(1.0) \mathrm{d} \\
82 \%^{\mathrm{ns}}\end{array}$ & $\begin{array}{c}9.1(0.1) \mathrm{d} \\
129 \%^{* *}\end{array}$ & $\begin{array}{c}26.4(2.3) \mathrm{c} \\
96 \%^{\mathrm{ns}}\end{array}$ & $\begin{array}{c}36.9(1.3) \mathrm{b} \\
112 \%^{\mathrm{ns}}\end{array}$ & $\begin{array}{c}61.3(1.3) \mathrm{a} \\
129 \%^{* *}\end{array}$ & $<0.0001$ \\
\hline \multirow[t]{2}{*}{ ST } & site-specific & $1.3(0.2) c$ & $3.9(0.5) c$ & $3.9(0.2) c$ & $17.6(1.4) \mathrm{b}$ & $21.9(0.7) b$ & $38.2(0.8) \mathrm{a}$ & $<0.0001$ \\
\hline & control & $\begin{array}{c}1.7(0.2) \mathrm{d} \\
129 \%^{\mathrm{ns}}\end{array}$ & $\begin{array}{c}4.1(0.8) \mathrm{d} \\
105 \%^{\mathrm{ns}}\end{array}$ & $\begin{array}{c}5.7(0.0) \mathrm{d} \\
145 \%^{* *}\end{array}$ & $\begin{array}{c}20.6(1.7) \mathrm{c} \\
117 \%^{\mathrm{ns}}\end{array}$ & $\begin{array}{c}28.2(1.0) \mathrm{b} \\
129 \%^{* *}\end{array}$ & $\begin{array}{c}52.0(0.9) \mathrm{a} \\
136 \% * * *\end{array}$ & $<0.0001$ \\
\hline \multirow[t]{2}{*}{ SW } & site-specific & $0.9(0.2) d$ & $3.0(0.4) \mathrm{d}$ & $2.9(0.2) \mathrm{d}$ & $14.1(1.2) \mathrm{c}$ & $17.7(0.6) b$ & $33.0(0.7) \mathrm{a}$ & $<0.0001$ \\
\hline & & $\begin{array}{c}1.2(0.2) \mathrm{d} \\
133 \% \text { * }\end{array}$ & $\begin{array}{c}3.0(0.6) \mathrm{d} \\
102 \%^{\mathrm{ns}}\end{array}$ & $\begin{array}{c}4.4(0.0) \mathrm{d} \\
150 \%^{* *}\end{array}$ & $\begin{array}{c}16.4(1.4) \mathrm{c} \\
117 \%^{\mathrm{ns}}\end{array}$ & $\begin{array}{c}22.9(0.8) b \\
129 \%^{* *}\end{array}$ & $\begin{array}{c}43.4(0.7) \mathrm{a} \\
131 \%^{* * * *}\end{array}$ & $<0.0001$ \\
\hline \multirow[t]{2}{*}{ SB } & site-specific & $0.4(0.1) c$ & $0.9(0.1) c$ & $1.0(0.0) \mathrm{c}$ & $3.5(0.3) b$ & $4.2(0.1) \mathrm{b}$ & $5.1(0.1) \mathrm{a}$ & $<0.0001$ \\
\hline & control & $\begin{array}{c}0.5(0.1) \mathrm{d} \\
120 \%^{\mathrm{ns}}\end{array}$ & $\begin{array}{c}1.1(0.2) \mathrm{d} \\
114 \%^{\mathrm{ns}}\end{array}$ & $\begin{array}{c}1.3(0.0) \mathrm{d} \\
132 \%^{* *}\end{array}$ & $\begin{array}{c}4.2(0.3) \mathrm{c} \\
119 \%^{\mathrm{ns}}\end{array}$ & $\begin{array}{c}5.3(0.2) \mathrm{b} \\
126 \%^{* *}\end{array}$ & $\begin{array}{c}8.6(0.1) \mathrm{a} \\
168 \%^{* * *}\end{array}$ & $<0.0001$ \\
\hline \multirow[t]{2}{*}{ BR } & site-specific & $1.9(0.3) b$ & $2.6(0.4) b$ & $3.1(0.1) b$ & $9.9(0.8) \mathrm{a}$ & $11.1(0.4) \mathrm{a}$ & $9.5(0.3) \mathrm{a}$ & $<0.0001$ \\
\hline & control & $\begin{array}{c}0.6(0.1) \mathrm{d} \\
35 \% * * *\end{array}$ & $\begin{array}{c}1.2(0.3) \mathrm{d} \\
48 \% * *\end{array}$ & $\begin{array}{c}3.4(0.1) \mathrm{c} \\
108 \% *\end{array}$ & $\begin{array}{c}5.8(0.5) \mathrm{b} \\
58 \% * *\end{array}$ & $\begin{array}{c}8.7(0.3) \text { a } \\
78 \% * *\end{array}$ & $\begin{array}{c}9.3(0.5) \mathrm{a} \\
98 \% \text { ns }\end{array}$ & $<0.0001$ \\
\hline FL & $\begin{array}{c}\text { site-specific } \\
\text { control }\end{array}$ & $\begin{array}{c}2.2(0.3) \mathrm{d} \\
1.2(0.2) \mathrm{c} \\
53 \%^{* *}\end{array}$ & $\begin{array}{c}3.3(0.5) \mathrm{cd} \\
1.4(0.3) \mathrm{c} \\
42 \% * *\end{array}$ & $\begin{array}{c}4.0(0.1) c \\
3.0(0.2) b \\
76 \%^{* *}\end{array}$ & $\begin{array}{c}6.6(0.5) \mathrm{ab} \\
4.4(0.4) \mathrm{a} \\
68 \%^{* *}\end{array}$ & $\begin{array}{c}6.8(0.2) \mathrm{a} \\
5.7(0.2) \mathrm{a} \\
84 \%^{* *}\end{array}$ & $\begin{array}{c}4.9(0.1) \mathrm{bc} \\
5.3(0.2) \mathrm{a} \\
108 \%^{\mathrm{ns}}\end{array}$ & $\begin{array}{c}0.0003 \\
<0.0001\end{array}$ \\
\hline
\end{tabular}

Abbreviations for tree biomass components: total aboveground biomass (AB), total aboveground woody biomass (ABW), total stem biomass (ST; SW+SB), stem wood biomass (SW), stem bark biomass (SB), branch biomass (BR) and foliage biomass (FL).

${ }^{1}$ Percent of differences in values obtained using control allometric equations in comparison with site-specific equations. Abbreviations: ns - not statistically significant; * - significant at $P<0.1 ;{ }^{* *}$ - significant at $P<0.05$; ${ }^{* * *}$ - significant at $P<0.01$.

stands. The biomass of particular organs of trees in the stands increased with stand age. Comparing the youngest (6 years) and oldest (20 years) stands, biomass of needles, branches and stems increased $1.3,4.1$, and 29 fold, respectively, when site-specific equations were used (Table 5).

We found several significant relationships among stand age and different biomass components, regardless of the allometric equation type used for biomass calculation. When site-specific allometric equations were used, there were significant positive relationships of the quadratic form among stand age and total aboveground biomass $\left(\mathrm{R}^{2}=0.98, P=0.0035\right)$, aboveground woody biomass $\left(\mathrm{R}^{2}=0.98, P=0.002\right)$, stem wood biomass $\left(\mathrm{R}^{2}=0.99, P=0.001\right)$, stem bark biomass $\left(\mathrm{R}^{2}=0.97, P=0.006\right)$ and stem biomass $\left(\mathrm{R}^{2}=0.99, P=0.0009\right)$. The weakest relationship was found for stand age and needles $\left(\mathrm{R}^{2}=0.84, P=0.062\right)$ and branch biomass $\left(\mathrm{R}^{2}=0.83, P=0.067\right)$, indicating that both biomass components were much more variable in the stands studied than other organs. Similar relationships were found when control equations were applied.

The stand age significantly influenced proportional allocation of biomass to particular organs of trees, regardless of the allometric equation type used for biomass estimation (Table 6). In general, the proportion of foliage and branch biomass decreased with increasing stand age, however the relationships were statistically significant only for foliage biomass $\left(\mathrm{R}^{2}=0.95, P=0.001\right.$ for site-specific equations; $\mathrm{R}^{2}=0.89, P=0.004$ for control equations). Moreover, the proportion of woody biomass components significantly increased with age; the lack of significant relationship was found only for proportional allocation to stem bark with stand age. Trajectories of changes were similar for both types of allometric equations used in the study.

\section{Discussion}

Our study has indicated that harsh environmental conditions (degraded soil, low soil nutrient concentrations) existing in spoil heaps from brown coal mining (Kowalik et al. 1999; Krzaklewski 2005; Świtoniak et al. 2013), affected $D_{1.3 m}$ and/or height of trees resulting in significant differences in biomass of young pine stands when calculated based on control equations developed for control stands from the 
same region. These results support the hypothesis that growing conditions may significantly modify allometric relationships due to differences in stand development trajectories. The largest differences were observed for needle and branch biomass, which are significantly higher in stands growing on spoil heaps than those expected based on allometric equations of the control stands (Table 5). We expected that aboveground biomass of stands grown on the extremely unfavorable site conditions of the spoil heap and calculated on the basis of site-specific allometric equations, would be lower due to slower tree growth, than biomass estimated from equations developed for control sites, where growing conditions were better. The opposite result that we obtained for the youngest stands (6 and 9 years old) might be partly explained by higher natural tree mortality in stands grown on the mine spoil heap due to harsh water conditions (there is no detectible ground water table) and severe deficiency of nutrients (Jagodziński and Kałucka 2008, 2010; Świtoniak et al. 2011), resulting in higher competition among trees than in the control stands. Densities of stands grown on the mine spoil heap were usually lower than those in the control sites (Table 1), which may have led to increased biomass allocation to needles and branches. For example, the proportions of needle biomass within aboveground biomass for stands grown on the control site were $c a 30.8,20.4,13.0$ and $5.6 \%$ for stands $6,10,16$ and 28 years old, respectively (data not shown), but were distinctly higher than these calculated for stands grown on the spoil heap,

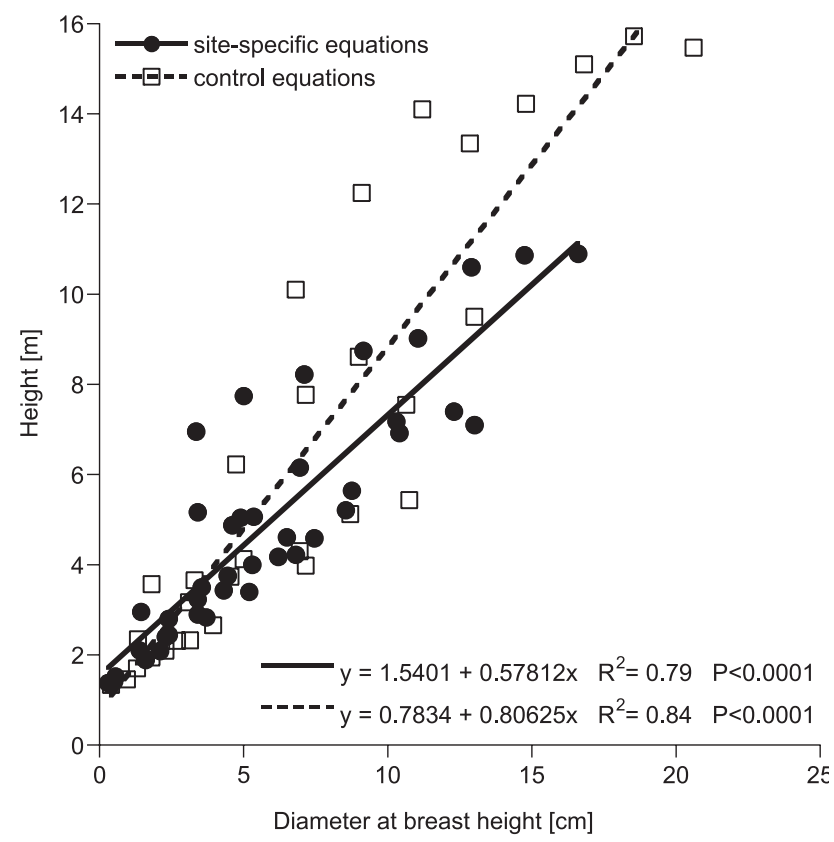

Fig. 1. Relationships between diameter at breast height and height of model trees harvested in stands grown on a mine spoil heap (site-specific equations) and control stands (control equations) using the site-specific equations (Table 6). The differences in the proportion of needle biomass in total aboveground stand biomass may be a result of lower stand density on the spoil heap in comparison with the control stands. This would cause better light penetration and greater needle longevity, since increased irradiances increases the proportional allocation of photosynthates to needle growth and development (Kellomäki 1981). Several previous studies indicate that better light conditions and more growing space per tree enable the trees to allocate more biomass to needles and branches (Kellomäki 1981; Vanninen et al. 1996; Wirth et al. 2002; Jagodziński and Oleksyn 2009a,b). Trees grown on infertile sites may also have increased needle longevity (Reich et al. 1996; Pensa et al. 2007). In addition, poorer growing conditions on the spoil heap in comparison with the control sites are clearly visible when diameter to height relationship of model trees is considered - most of the trees with $\mathrm{D}_{1.3 \mathrm{~m}}>7 \mathrm{~cm}$ harvested in the control sites were taller than trees with similar diameters harvested on the spoil heap (Fig. 1).

The ratios of needle to branch biomass for stands grown on the spoil heap are higher than for the control stands. For example, this ratio is 1.2, 1.3 and 1.3 in stands 6, 9 and 11 years old, respectively, and 0.7, 0.6 and 0.5 in stands 15, 17, and 20 years old (when biomass of needles and branches was estimated by site-specific equations), while for the control stands the ratios were $0.99,0.56,0.61$ and 0.35 for stands $6,10,16$ and 28 years old (data not shown; biomass estimated by site-specific equations for each stand separately). This data supports the assumption that site conditions may alter biomass allocation.

Our data revealed a marked influence of growth conditions on parameters of site-specific and control allometric equations, resulting in highly significant differences in predicted biomass allocation and accumulation when control (as opposed to site-specific) equations were applied to stands growing in harsh conditions existing on the spoil heap. Our data has indicated that control allometric equations may underestimate total aboveground biomass of young stands (6 to 9 years old), by ca. $30 \%$. In the older stands, e.g. 15 to 20 years old, the total aboveground biomass may be overestimated by 7 to $27 \%$ (Table 5). Since these biomass estimates exceeded the commonly accepted uncertainty level of $10 \%$ (Hamburg 2000), tree biomass for harsh conditions such as on mine spoil heaps should be calculated by site-specific equations.

The present study revealed changes in biomass partitioning with stand age. Our data showed that biomass production and proportional allocation to different organs, calculated on the basis of site-specific equations, depended on stand age. In general, total aboveground biomass of stands in our study was 
Table 6. Mean proportional biomass allocation to different components [\%; \pm SE] in aboveground biomass of Scots pine stands differing in age estimated on the basis of two equation types (site-specific and control delivered from nearby control stands). One-way ANOVAs were performed separately for particular biomass components to check differences among stands differing in age (horizontally) and within the stand among biomass obtained by site-specific and control equations (vertically). Same letters indicate a lack of statistically significant differences between analyzed stand traits according to Tukey's a posteriori test $(P<0.05)$. Abbreviations as in Table 2.

\begin{tabular}{|c|c|c|c|c|c|c|c|c|}
\hline \multirow{2}{*}{$\begin{array}{l}\text { Biomass } \\
\text { component }\end{array}$} & \multirow{2}{*}{$\begin{array}{l}\text { Equation } \\
\text { type }\end{array}$} & \multicolumn{6}{|c|}{ Stand age } & \multirow{2}{*}{$\begin{array}{c}\text { ANOVA } \\
\mathrm{P}>\mathrm{F}\end{array}$} \\
\hline & & 6 & 9 & 11 & 15 & 17 & 20 & \\
\hline \multirow[t]{3}{*}{ ABW } & site-specific & $58.9(0.8) \mathrm{d}$ & $66.6(0.0) \mathrm{c}$ & $63.9(1.2) c$ & $80.7(0.1) b$ & $83.0(0.0) \mathrm{b}$ & $90.6(0.0) \mathrm{a}$ & $<0.0001$ \\
\hline & control & $66.5(0.0) \mathrm{e}$ & $79.5(0.1) \mathrm{c}$ & $75.0(1.2) \mathrm{d}$ & $85.6(0.0) \mathrm{b}$ & $86.6(0.0) \mathrm{b}$ & $92.0(0.1) \mathrm{a}$ & $<0.0001$ \\
\hline & ANOVA $P>F$ & 0.0100 & $<0.0001$ & 0.0223 & 0.0009 & $<0.0001$ & 0.0042 & \\
\hline \multirow[t]{3}{*}{ ST } & site-specific & $24.0(0.5) \mathrm{f}$ & $40.2(0.3) d$ & $35.6(1.2) \mathrm{e}$ & $51.7(0.0) \mathrm{c}$ & $55.1(0.0) \mathrm{b}$ & $72.6(0.2) \mathrm{a}$ & $<0.0001$ \\
\hline & control & $47.9(0.4) \mathrm{d}$ & $61.2(0.4) \mathrm{c}$ & $47.2(0.4) d$ & $66.8(0.2) b$ & $66.3(0.0) \mathrm{b}$ & $78.1(0.5) \mathrm{a}$ & $<0.0001$ \\
\hline & ANOVA $P>F$ & 0.0006 & 0.0006 & 0.0114 & 0.0001 & $<0.0001$ & 0.0086 & \\
\hline \multirow[t]{3}{*}{ SW } & site-sp & $17.0(0.3) \mathrm{f}$ & $30.5(0.1) \mathrm{d}$ & $26.5(1.0) \mathrm{e}$ & $41.3(0.1) \mathrm{c}$ & $44.6(0.0) \mathrm{b}$ & $62.8(0.2) \mathrm{a}$ & $<0.0001$ \\
\hline & & $34.9(0.1) \mathrm{d}$ & $45.0(0.3) \mathrm{c}$ & $36.1(0.3) \mathrm{d}$ & $53.2(0.0) \mathrm{b}$ & $53.8(0.1) \mathrm{b}$ & $65.2(0.3) \mathrm{a}$ & $<0.0001$ \\
\hline & ANOVA $\mathrm{P}>\mathrm{F}$ & 0.0003 & 0.0004 & 0.0120 & $<0.0001$ & $<0.0001$ & 0.0271 & \\
\hline \multirow[t]{3}{*}{ SB } & site-specific & $7.0(0.1) \mathrm{d}$ & $9.7(0.2) b c$ & $9.2(0.2) \mathrm{c}$ & $10.3(0.1) \mathrm{ab}$ & $10.5(0.0) \mathrm{a}$ & $9.8(0.0) b c$ & $<0.0001$ \\
\hline & control & $13.0(0.3) \mathrm{b}$ & $16.2(0.7) \mathrm{a}$ & $11.1(0.0) \mathrm{c}$ & $13.6(0.1) \mathrm{b}$ & $12.4(0.0) b c$ & $13.0(0.1) \mathrm{b}$ & 0.0003 \\
\hline & ANOVA $\mathrm{P}>\mathrm{F}$ & 0.0027 & 0.0105 & 0.0086 & 0.0021 & 0.0002 & 0.0015 & \\
\hline \multirow[t]{3}{*}{ BR } & site-specific & $34.9(0.3) \mathrm{a}$ & $26.5(0.3) \mathrm{d}$ & $28.2(0.0) b c$ & $29.1(0.1) b$ & $27.9(0.0) c$ & $18.0(0.2) \mathrm{e}$ & $<0.0001$ \\
\hline & control & $18.6(0.4) b$ & $18.3(0.5) b$ & $27.9(0.8) \mathrm{a}$ & $18.8(0.1) b$ & $20.4(0.0) \mathrm{b}$ & $13.9(0.4) \mathrm{c}$ & $<0.0001$ \\
\hline & ANOVA $\mathrm{P}>\mathrm{F}$ & 0.0009 & 0.0054 & 0.6881 & 0.0002 & $<0.0001$ & 0.0105 & \\
\hline \multirow[t]{2}{*}{ FL } & site-specific & $41.1(0.8) \mathrm{a}$ & $33.4(0.0) \mathrm{b}$ & $36.1(1.2) \mathrm{b}$ & $19.3(0.1) \mathrm{c}$ & $17.0(0.0) \mathrm{c}$ & $9.4(0.0) d$ & $<0.0001$ \\
\hline & $\begin{array}{c}\text { control } \\
\text { ANOVA } \mathrm{P}>\mathrm{F}\end{array}$ & $\begin{array}{c}33.5(0.0) \mathrm{a} \\
0.0100\end{array}$ & $\begin{array}{c}20.5(0.1) c \\
<0.0001\end{array}$ & $\begin{array}{c}25.0(1.2) \mathrm{b} \\
0,0223\end{array}$ & $\begin{array}{c}14.4(0.0) \mathrm{d} \\
0.0009\end{array}$ & $\begin{array}{c}13.4(0.0) \mathrm{d} \\
<0.0001\end{array}$ & $\begin{array}{c}8.0(0.1) \mathrm{e} \\
0.0042\end{array}$ & $<0.0001$ \\
\hline
\end{tabular}

higher than reported by Ovington (1957) for Scots pine stands with a similar age range. For example, total aboveground biomass in our sites was 17 and $20 \%$ higher in stands 17 and 20 years old, than for stands of the same age from the cited study. Such a result was unexpected since our stands grow on an inherently infertile substrate and growing conditions on the mine spoil heap are not very favorable (e.g. lack of groundwater, deficiency of nutrients, low organic matter, degraded soil) (Hołubowicz 1985; Kowalik et al. 1999; Krzaklewski 2005; Świtoniak et al. 2011, 2013). Furthermore, better site quality may promote biomass production (Albrektson 1980; Vanninen et al. 1996), thus the lower biomass in Ovington (1957) study in comparison with our data suggests that other factors may play a crucial role in biomass production. Apart from that, the changes of biomass production per hectare with age in both studies may reflect changes in stand density following traditional stand management (initial stand density, pre-commercial thinning treatments; Jagodziński and Oleksyn 2009a,b). For example, in our study stand density significantly decreased with age $\left(\mathrm{R}^{2}=0.83\right.$, $P=0.01$ ), while in the Ovington (1957) study stand densities in older stands (i.e. 14, 17, and 20 years old) were higher than in the youngest $(3,7$, and 11 year old) stands.

Biomass accumulation in even-aged, single-species stands may be very variable even if they grow in similar conditions. For example, Oleksyn et al. (2000) found that 16-year-old Scots pine stands from 19 geographically distinct populations grown in a common garden experiment in central Poland $\left(52^{\circ} \mathrm{N}\right)$ produced 0.8 to $8.4 \mathrm{Mg}$ needles $\mathrm{ha}^{-1}$ and 9.4 to $72.5 \mathrm{Mg} \mathrm{ha}^{-1}$ of total aboveground biomass, although at the same time, the proportion of foliage biomass within total aboveground biomass was very narrow (approximately $8.8 \%, 9.4 \%$, and $11.0 \%$ for Scots pine populations of southern, northern and central origin, respectively). Foliage biomass of northern (3.0 Mg ha ${ }^{-1}$ ) and southern (1.2 $\mathrm{Mg} \mathrm{ha}^{-1}$ ) populations in the Oleksyn et al. (2000) study were distinctly lower in comparison with our data (mean of 15- and 17-year-old stands), whereas mean foliage biomass of central populations $\left(6.6 \mathrm{Mg} \mathrm{ha}^{-1}\right)$ was similar to ours (i.e. $6.7 \mathrm{Mg} \mathrm{ha}^{-1}$ ). At the same time most of the stands of central origin described by Oleksyn et al. (2000) had considerably higher total aboveground biomass than in our study, whereas northern and southern populations revealed significantly lower total aboveground biomasses. The higher crop biomass of central populations in their study may be due to better growth conditions (forest soil, higher nutrient and water availability) in comparison with ours, whereas the lower crop biomass of southern and northern populations may be a result of higher tree mortality and altered biomass allocation patterns since nutrients affect growth by changing biomass allocation and tree size primarily modifies biomass allocation (Portsmuth et al. 2005). The fact that the mean foliage biomass proportion for 15 - and 17-year-old stands was $18 \%$ in our study, 
but only $11 \%$ (and fairly stable among population origins) in Oleksyn et al. (2000), despite very similar stand densities between the two studies (5074 and 4761 trees $\mathrm{ha}^{-1}$, respectively), confirms that poor site conditions may promote biomass allocation to foliage (see also Reich et al. 1996; Vanninen and Mäkelä 2005). In conclusion, both our data and works published previously by other authors have shown that foliage biomass is very difficult to predict with satisfactory precision because of its high variation related to site condition and stand properties. Thus, the prediction of foliage biomass for a given site based on results obtained from other sites, should be done with caution.

In summary, results of our study indicate that growth conditions and stand features significantly influenced allometrically derived estimates of tree biomass generated using control equations of tree biomass from a Scots pine chronosequence. The data revealed that the biomass of stands growing under harsh environment conditions (degraded soil, low soil nutrient concentration and water deficit) existing in mine spoil heaps significantly differed from values calculated based on control equations developed for the same region but for the stands growing on more fertile soils. These differences may be due to differences in stand structure resulting from higher tree mortality on the spoil heap and changes in tree growth trajectory. It is likely that control biomass equations may not be suitable to satisfactorily estimate biomass accumulation and proportional allocation in stands growing on disturbed or infertile and dry habitats, even if the control equations are developed for nearby stands, but grown on better site conditions.

\section{Acknowledgements}

This study was partially supported by the Institute of Dendrology, Polish Academy of Sciences, Kórnik, Poland, by the General Directorate of State Forests, Warsaw, Poland (research project: 'Environmental and genetic factors affecting productivity of forest ecosystems on forest and post-industrial habitats'), and by the State Committee for Scientific Research, Poland (grant no. 3 P04G 031 23). We thank Mr. Kazimierz Grochulski from the Bełchatów Forest District for valuable help with field work and Dr. Lee E. Frelich (University of Minnesota, USA) for linguistic support.

\section{References}

Albrektson A. 1980. Relations between tree biomass fractions and conventional silvicultural measurements. Ecological Bulletins (Stockholm) 32: 315327.

Bell L.C. 2001. Establishment of native ecosystems after mining - Australian experience across diverse biogeographic zones. Ecological Engineering 17: 179-186. http://dx.doi.org/10.1016/ S0925-8574(00)00157-9

Bijak Sz., Zasada M., Bronisz A., Bronisz K., Czajkowski M., Ludwisiak Ł., Tomusiak R., Wojtan R. 2013. Estimating coarse roots biomass in young silver birch stands on post-agricultural lands in central Poland. Silva Fennica 47: 1-14.

Chmura D.J., Guzicka M., Rożkowski R., Chałupka W. 2013. Variation in aboveground and belowground biomass in progeny of selected stands of Pinus sylvestris. Scandinavian Journal of Forest Research 28: 724-734. http://dx.doi.org/10.1080/0 2827581.2013.844269

Concise Statistical Yearbook of Poland 2007. Główny Urząd Statystyczny, Warszawa.

Dubaniewicz M. 1979. Klimat. In: Województwo piotrkowskie. Monografia regionalna. Zarys dziejów, obraz współczesny, perspektywy rozwoju. Stankiewicz Z. (ed.). Uniwersytet Łódzki, Łódź Piotrków Trybunalski.

Filcheva E., Noustorova M., Gentcheva-Kostadinova S., Haigh M.J. 2000. Organic accumulation and microbial action in surface coal-mine spoils, Pernik, Bulgaria. Ecological Engineering 15: 1-15. http:// dx.doi.org/10.1016/S0925-8574(99)00008-7

Gower S.T., Gholz H.L., Nakane K., Baldwin V.C. 1994. Production and carbon allocation patterns of pine forests. Ecological Bulletins 43: 115-135.

Hamburg S.P. 2000. Simple rules for measuring changes in ecosystem carbon in forestry-offset projects. Mitigation and Adaptation Strategies for Global Change 5: 25-37. http://dx.doi. org/10.1023/A:1009692114618

Harris J.A., Hobbs R.J., Higgs E., Aronson J. 2006. Ecological restoration and global climate change. Restoration Ecology 14: 170-176. http://dx.doi. org/10.1111/j.1526-100X.2006.00136.x

Hołubowicz K. 1985. Rekultywacja i zagospodarowanie zwałowisk Kopalni Węgla Brunatnego „Bełchatów”. In: Zmiany w środowisku przyszłego Bełchatowskiego Okręgu Przemysłowego. Stan z okresu przedinwestycyjnego i wstępnej fazy pracy elektrowni. Liszewski S. (ed.). Uniwersytet Łódzki, PWN, Warszawa - Łódź, pp. 273-285.

Jagodziński A.M., Kałucka I. 2008. Age-related changes in leaf area index of young Scots pine stands. Dendrobiology 59: 57-65. 
Jagodziński A.M., Kałucka I. 2010. Fine roots biomass and morphology in a chronosequence of young $\mathrm{Pi}$ nus sylvestris stands growing on a reclaimed lignite mine spoil heap. Dendrobiology 64: 19-30.

Jagodziński A.M., Kałucka I. 2011. Fine root biomass and morphology in an age-sequence of post-agricultural Pinus sylvestris L. stands. Dendrobiology 66: 71-84.

Jagodziński A.M., Oleksyn J. 2009a. Ekologiczne konsekwencje hodowli drzew w różnym zagęszczeniu. I. Wzrost i rozwój drzewostanu. Sylwan 153: $75-85$.

Jagodziński A.M., Oleksyn J. 2009b. Ekologiczne konsekwencje hodowli drzew w różnym zagęszczeniu. II. Produkcja i alokacja biomasy, retencja biogenów. Sylwan 153: 147-157.

Jelonek T., Pazdrowski W., Walkowiak R., Arasimowicz-Jelonek M., Tomczak A. 2011. Allometric models of foliage biomass in Scots pine (Pinus sylvestris L.). Polish Journal of Environmental Studies 20: 355-364.

Kellomäki S. 1981. Effect of the within-stand light regime on the share of stem, branch and needle growth in a twenty-year-old Scots pine stand. Silva Fennica 15: 130-139. http://dx.doi. org/10.14214/sf.a15052

Knight D.H., Vose J.M., Baldwin V.C., Ewel K.C., Grodzinska K. 1994. Contrasting patterns in pine forest ecosystems. Ecological Bulletins 43: 9-19.

Kolari P., Pumpanen J., Rannik U., Ilvesniemi H., Hari P., Berninger F. 2004. Carbon balance of different aged Scots pine forests in Southern Finland. Global Change Biology 10: 1106-1119. http://dx.doi. org/10.1111/j.1529-8817.2003.00797.x

Kowalik S., Krzaklewski W., Wójcik J. 1999. Skuteczność neutralizacji toksycznie kwaśnych gruntów na zwałowisku zewnętrznym KWB „Bełchatów”. Inżynieria Środowiska 4: 395-410.

Krzaklewski W. 2005. Rekultywacja w KWB „Bełchatów" - zamierzenia, stan i perspektywy. Prace Naukowe Instytutu Górnictwa Politechniki Wrocławskiej 112, Konferencje 44: 411-421.

Law B.E., Sun O.J., Campbell J., Van Tuyl S., Thornton P.E. 2003. Changes in carbon storage and fluxes in a chronosequence of ponderosa pine. Global Change Biology 9: 510-524. http://dx.doi. org/10.1046/j.1365-2486.2003.00624.x

Litton C.M., Raich J.W., Ryan M.G. 2007. Carbon allocation in forest ecosystems. Global Change $\mathrm{Bi}-$ ology 13: 2089-2109. http://dx.doi.org/10.1111/ j.1365-2486.2007.01420.x

Lorenz K., Lal R. 2010. Carbon Sequestration in Forest Ecosystems. Springer Science+Business Media B.V. Dordrecht, Heidelberg, London, New York.

Mund M., Kummetz E., Hein M., Bauer G.A., Schulze E.D. 2002. Growth and carbon stocks of a spruce forest chronosequence in central Europe. Forest Ecology and Management 171: 275-296. http:// dx.doi.org/10.1016/S0378-1127(01)00788-5

Muukkonen P., Mäkipää R., 2006. Biomass equations for European trees: addendum. Silva Fennica 40: 763-773. http://dx.doi.org/10.14214/sf.475

Oleksyn J., Reich P.B., Chalupka W., Tjoelker M.G. 1999. Differential above- and below-ground biomass accumulation of European Pinus sylverstris populations in a 12-year-old provenance experiment. Scandinavian Journal of Forest Research 14: 7-17. http://dx.doi. org/10.1080/02827589908540804

Oleksyn J., Reich P.B., Rachwal L., Tjoelker M.G., Karolewski P. 2000. Variation in aboveground net primary production of diverse European Pinus sylvestris populations. Trees 14: 415-421. http://dx. doi.org/10.1007/PL00009775

Oleksyn J., Reich P.B., Zytkowiak R., Karolewski P., Tjoelker M.G. 2002. Needle nutrients in geographically diverse Pinus sylvestris L. populations. Annals of Forest Science 59: 1-18. http://dx.doi. org/10.1051/forest:2001001

Oleksyn J., Reich P.B., Zytkowiak R., Karolewski P., Tjoelker M.G. 2003. Nutrient conservation increases with latitude of origin in European Pinus sylvestris populations. Oecologia 136: 220-235. http://dx.doi.org/10.1007/s00442-003-1265-9

Ovington J.D. 1957. Dry-matter production by Pinus sylvestris L. Annals of Botany 21: 287-314.

Pająk M., Krzaklewski W. 2007. Selected physical properties of initial soils on the outside spoil bank of the Bełchatów brown coal mine. Journal of Forest Science 53: 308-313.

Pensa M., Jalkanen R., Liblik V. 2007. Variation in Scots pine needle longevity and nutrient conservation in different habitats and latitudes. Canadian Journal of Forest Research 37: 1599-1604. http://dx.doi.org/10.1139/X07-012

Pietrzykowski M., Krzaklewski W. 2007. An assessment of energy efficiency in reclamation to forest. Ecological Engineering 30: 341-348. http:// dx.doi.org/10.1016/j.ecoleng.2007.04.003

Pietrzykowski M., Socha J. 2011. An estimation of Scots pine (Pinus sylvestris L.) ecosystem productivity on reclaimed post-mining sites in Poland (central Europe) using of allometric equations. Ecological Engineering 37: 381-386. http://dx. doi.org/10.1016/j.ecoleng.2010.10.006

Pietrzykowski M., Socha J., Krzaklewski W. 2009. Perspektywy pozyskania energii z biomasy drzewostanów na zrekultywowanym zwałowisku zewnętrznym KWB "Bełchatów". Górnictwo i Geoinżynieria 33: 373-381.

Poorter H., Niklas K.J., Reich P.B., Oleksyn J., Poot P., Mommer L. 2012. Biomass allocation to leaves, stems and roots: meta-analyses of interspecific 
variation and environmental control. New Phytologist 193: 30-50. http://dx.doi.org/10.1111/ j.1469-8137.2011.03952.x

Portsmuth A., Niinemets Ü., Truus L., Pensa M. 2005. Biomass allocation and growth rates in $\mathrm{Pi}$ nus sylvestris are interactively modified by nitrogen and phosphorus availabilities and by tree size and age. Canadian Journal of Forest Research 35: 2346-2359. http://dx.doi.org/10.1139/x05-155

Pregitzer K.S., Euskirchen E.S. 2004. Carbon cycling and storage in world forests: biome patterns related to forest age. Global Change Biology 10: 2052-2077. http://dx.doi.org/10.1111/j.13652486.2004.00866.x

Řehounková K., Prach K. 2008. Spontaneous vegetation succession in gravel-sand pits: a potential for restoration. Restoration Ecology 16: 305-312. http://dx.doi.org/10.1111/j.1526100X.2007.00316.x

Reich P.B. 2011. Taking stock of forest carbon. Nature Climate Change 1: 346-347. http://dx.doi. org/10.1038/nclimate1233

Reich P.B., Oleksyn J. 2004. Global patterns of plant leaf $\mathrm{N}$ and $\mathrm{P}$ in relation to temperature and latitude. Proceedings of the National Academy of Sciences of the USA 101: 11001-11006. http:// dx.doi.org/10.1073/pnas.0403588101

Reich P.B., Oleksyn J., Modrzynski J., Tjoelker M.G. 1996. Evidence that longer needle retention of spruce and pine populations at high elevations and high latitudes is largely a phenotypic response. Tree Physiology 16: 643-647. http://dx. doi.org/10.1093/treephys/16.7.643

Shrestha R.K., Lal R. 2006. Ecosystem carbon budgeting and soil carbon sequestration in reclaimed mine soil. Environment International 32: 781-796. http://dx.doi.org/10.1016/j.envint.2006.05.001

Smith J. 2002. Afforestation and reforestation in the clean development mechanism of the Kyoto Protocol implications for forests and forest people. International Journal of Global Environmental Issues 2: 322-343. http://dx.doi.org/10.1504/IJGENVI.2002.002406

Świtoniak M., Hulisz P., Kałucka I., Różański S. 2011. Rola monokultur sosnowych w kształtowaniu zasobów węgla organicznego w glebach zwałow- iska zewnętrznego KWB Bełchatów. Roczniki Gleboznawcze 62: 395-405.

Świtioniak M., Hulisz P., Różański S., Kałucka I. 2013. Soils of the external dumping ground of the Bełchatów open-cast lignite mine. In: Technogenic soils of Poland. Charzyński P., Hulisz P., Bednarek R. (eds). Polish Society of Soil Science, Toruń, pp. 255-274.

Ter-Mikaelian M.T., Korzukhin M.D. 1997. Biomass estimations for 65 North American tree species. Forest Ecology and Management 97: 1-24. http:// dx.doi.org/10.1016/S0378-1127(97)00019-4

Uri V., Varik M., Aosaar J., Kanal A., Kukumägi M., Lõhmus K. 2012. Biomass production and carbon sequestration in a fertile silver birch (Betula pendula Roth) forest chronosequence. Forest Ecology and Management 267: 117-126. http://dx.doi. org/10.1016/j.foreco.2011.11.033

Ussiri D.A.N., Lal R. 2005. Carbon sequestration in reclaimed minesoils. Critical Reviews in Plant Sciences 24: 151-165. http://dx.doi. org/10.1080/07352680591002147

Vanninen P., Mäkelä A. 2005. Carbon budget for Scots pine trees: effects of size, competition and site fertility on growth allocation and production. Tree Physiology 25: 17-30. http://dx.doi. org/10.1093/treephys/25.1.17

Vanninen P., Ylitalo H., Sievänen R., Mäkelä A. 1996. Effects of age and site quality on the distribution of biomass in Scots pine (Pinus sylvestris L.). Trees 10: 231-238.

Vose J.M., Dougherty P.M., Long J.N., Smith F.W., Gholz H.L., Curran P.J. 1994. Factors influencing the amount and distribution of leaf area of pine stands. Ecological Bulletins 43: 102-114.

Wirth C., Schulze E.D., Kusznetova V., Milyukova I., Hardes G., Siry M., Schulze B., Vygodskaya N.N. 2002. Comparing the influence of site quality, stand age, fire and climate on aboveground tree production in Siberian Scots pine forests. Tree Physiology 22: 537-552. http://dx.doi. org/10.1093/treephys/22.8.537

Zianis D., Muukkonen P., Mäkipää R., Mencuccini M. 2005. Biomass and stem volume equations for tree species in Europe. Silva Fennica Monographs 4: 2-63. 